\title{
Future of water in Europe II: strategies for 2020 and beyond
}

\author{
Kemi Adeyeye $^{1} \cdot$ Carla Pimental Rodrigues $^{2} \cdot$ Armando Silva Afonso $^{2}$ \\ Published online: 27 January 2020 \\ (C) Springer-Verlag GmbH Germany, part of Springer Nature 2020
}

The uncertainties of climate change, weather variability and the over-exploitation of natural resources including water have meant that business-as-usual practices are untenable and new resource strategies are needed. Globally, and in Europe, policy-makers, businesses, markets and individuals are collectively acting to transition towards a more sustainable future by promoting renewable resources, resource efficiency and resilience of people and environments.

This Special Issue of the Environmental Science and Pollution Research contains a selection of 7 papers presented at the 5th Water Efficiency Conference - WATEFCON 2018 organized by the Water Efficiency Network. The conference held at the University of Aveiro in Aveiro, Portugal, from September 5 to 7, 2018, was chaired by Dr. Carla Pimental Rodrigues and Prof. Armando Silva Afonso.

The Water Efficiency conference series, organized by the Water Efficiency Network (www.watefnetwork.co.uk), has been taking place since 2013. The network is a global group of academics, industry practitioners, NGOs, interest groups and members of the public who share a common interest in promoting water resource efficiency and resilience, progressive water policy and standards and good social and environmental water practices. The network was established in 2011 with the support of the UK Government's Department for Environment, Food \& Rural Affairs (DEFRA) and

Responsible editor: Philippe Garrigues

Kemi Adeyeye

k.adeyeye@bath.ac.uk

Carla Pimental Rodrigues

anqip@anqip.pt

Armando Silva Afonso

asilva.afonso@outlook.pt

1 Department of Architecture and Civil Engineering, University of Bath, Bath, UK

2 ANQIP - Associação Nacional para a Qualidade nas Instalações Prediais, University of Aveiro, Aveiro, Portugal remains successful, thanks to its many dedicated members and technical committees.

The Water Efficiency Conference WATEFCON 2018, the network's 5th conference, explored the various questions that could impact on future water resources in Europe. It also proposed solutions and strategies on how the quantity and quality of water can be preserved, how water can be used more efficiently and how its inherent properties can be exploited to generate renewable energy. The proceedings, in addition to the conference papers, included 3 keynote lectures from leading water experts in Europe and 2 industry sessions. The first industry session on Water Labelling was organized in collaboration with ANQIP (Associação Nacional para a Qualidade nas Instalações Prediais). The second industry session was on Micro Hydro Energy Recovery and System Control towards Smart Water organized in collaboration with the EU Interreg Atlantic Area project, REDAWN (Reducing Energy Dependencies in Atlantic Area Water Networks) (www. redawn.eu).

This Special Issue is the second from the WATEFCON 2018. It contains a selection of papers which address water resource issues from the urban scale to the building scale, as well as from the socio-technical perspective. The first two papers address issues of water quality and water supply resilience; the next three focussed on urban and alternative water supply, followed by two papers on water-energy nexus at the building scale. The last paper explored user-product interactions to improve water efficiency and labelling.

The seven papers included in this special edition are entitled as follows:

1. Risk management in water supply networks: Aveiro case study

2. State of a Sustainable Drainage System at end-of-life: Assessment of Potential Water Pollution by Leached Metals from Recycled Pervious Pavement Materials when used as Secondary Aggregate

3. Complexity-balanced method for urban scale rainwater harvesting simulation 
4. Performance Assessment of Water Reuse Strategies using Integrated Framework of Urban Water Metabolism and Water-Energy-Pollution Nexus

5. Assessing water, energy and emissions reduction from water conservation measures in buildings: a methodological approach

6. Increasing water and energy efficiency in university buildings: A case study

7. Beyond the flow rate: the importance of thermal range, flow intensity and distribution for water efficient showers

Acknowledgements The guest editors would like to thank all the authors for the groundbreaking scientific and professional contributions to the conference and this special issue. We thank all the academic and industry keynote speakers and panellists, session chairs, strategic partners, policy and industry supporters and sponsors and reviewers for the conference proceedings. We are particularly grateful to the reviewers of the papers in this issue - their comments and feedback led to the high-quality papers published herein.

Special thanks to Prof Philippe Garrigues, ESPR Editor-in-Chief, and the editorial team of Fanny Creusot, Florence Delavaud, Joanne Cabato and others, for their positive support, their professionalism and their efforts towards the successful compilation of this special issue.

Publisher's note Springer Nature remains neutral regarding jurisdictional claims in published maps and institutional affiliations.

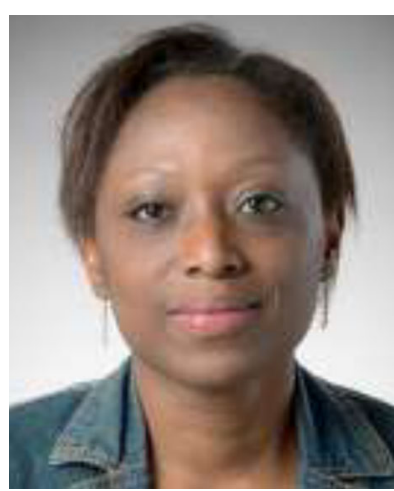

Dr Kemi Adeyeye is an academic, chartered architectural technologist (CIAT) and chartered surveyor (RICS). She specialises in integrated design and her research focusses on the multi-disciplinary and multi-factorial aspects of resource efficiency and resilience. This work focusses on all aspects of water in the built environment including people, product, process and policy. She also currently leads the Water Efficiency Network (www.watefnetwork.co. uk). She has over 60 publications including books, book chapters, and journal and conference papers.

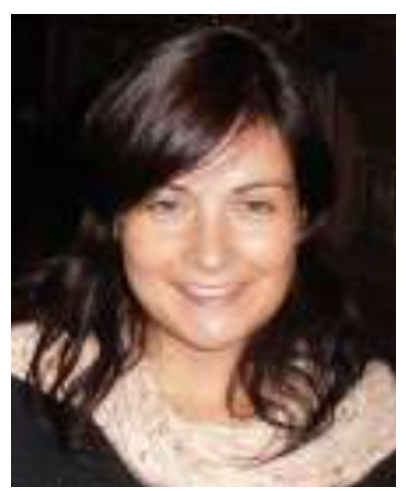

Carla Pimentel Rodrigues holds a $\mathrm{PhD}$ from the University of Aveiro (Portugal) in Civil Engineering (water efficiency). She is a technical director at ANQIP - National Association for Quality in Building Installations and is also a member of the Research Centre RISCO at the University of Aveiro. She he has published 2 books in the field of water efficiency in buildings and one chapter in an international book.

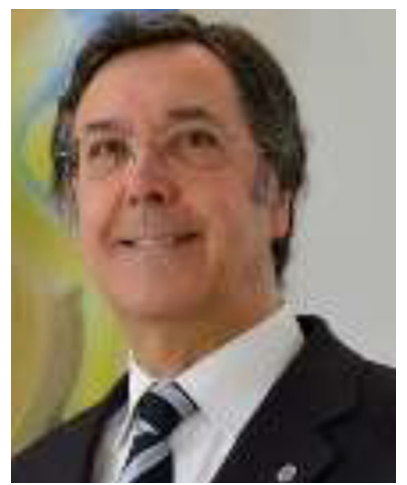

Professor Armando SivaAfonso is a retired full professor of the University of Aveiro (Portugal), Department of Civil Engineering, where he continues to collaborate as a visiting professor. His specializations are hydraulics and water efficiency. He is the founder and president of the Board of ANQIP - Portuguese Association for Quality and Efficiency in Building Installations, counsellor member of the Portuguese Engineers' Association and current president of the Board of Directors of the Centre Region of this Association. He is also an invited expert of the European Commission in the field of Water Efficiency in Buildings and a member of the IWA - International Water Association and Member of Working Group W062 - Water Supply and Drainage for Buildings, from CIB - International Council for Research and Innovation in Building and Construction. He was a former USAID consultant for Portugal (1989/91), in the field of the efficient use of recourses and energy in cities. As a consulting engineer (hydraulics and sanitation), he has developed projects in several countries, such as Portugal, Angola, Guinea, Cape Verde, Mozambique, São Tomé and Príncipe, Ghana, Senegal and Egypt. 